\title{
Kepemimpinan Etis: Rahasia Menurunkan Stres Kerja dan Turnover Intention
}

\author{
Bonar Bangun Jeppri Napitupulu ${ }^{1 *}$, Gusti Nyoman Budiadnyana², \\ Muhammad Johan $^{1}$, Admiral ${ }^{1}$, Dewiana Novitasari ${ }^{1}$ \\ ${ }^{1}$ Sekolah Tinggi Ilmu Ekonomi Insan Pembangunan, Tangerang, Indonesia \\ ${ }^{2}$ STMIK Insan Pembangunan, Tangerang, Indonesia \\ *jemhrd@gmail.com
}

\begin{abstract}
This study aims to examine the effect of ethical leadership on turnover intention and to investigate the mediating effect of job stress on the employee of a garment industry in Indonesia. Data was collected from 184 returned questionnaires of samples taken by random sampling. The data were analysed using an SEM method with SmartPLS 3.0 software. The results of this study show that ethical leadership has a negative significant effect of job stress and employee turnover intention, job stress has a positive significant effect on turnover intention. This new research proposed a model for managing job stress and turnover intention among the employee of the garment industry in Indonesia through developing ethical leadership practice. This research could pave the way to improve employee readiness in facing the era of industrial revolution 4.0.
\end{abstract}

Keywords: Ethical Leadership, Job Stress, Turnover Intention

\section{PENDAHULUAN}

Studi tentang turnover intention menjadi semakin penting dalam konteks manajemen dan perilaku organisasi (Lin \& Liu, 2017; Shafique et al., 2018). Penelitian telah menunjukkan bahwa niat keluar masuk karyawan sangat mempengaruhi kinerja industri manufaktur di Indonesia karena menyebabkan semakin kurangnya karyawan yang memenuhi syarat (Shareef \& Atan, 2019). Apa sebenarnya yang mendorong orang untuk mengembangkan niat untuk meninggalkan pekerjaannya? Beberapa literatur telah mengidentifikasi berbagai alasan di balik niat keluar masuk karyawan. Beberapa peneliti telah mencatat bahwa konteks sosial, seperti sejauh mana karyawan merasa didukung dan berkomitmen terhadap tempat kerja, dapat mempengaruhi niat untuk pergi (Asbari, Novitasari, \& Goestjahjanti,
2020; Asbari, Novitasari, Gazali, et al., 2020; Asbari \& Novitasari, 2020a, 2021a; Asbari \& Prasetya, 2021; Nazelina et al., 2020; Novitasari, Asbari, et al., 2020; Novitasari, Goestjahjanti, et al., 2020; Novitasari et al., 2021; Novitasari \& Asbari, 2020b). Studi juga menunjukkan fakta bahwa dukungan pada organisasi yang dirasakan/perceived organizational support (POS), komitmen, keamanan kerja dan kepercayaan adalah anteseden utama dari niat keluar masuk karyawan (Mullen et al., 2018). Namun, sebagian besar penelitian ini telah dilakukan dilakukan dalam studi terpisah, dan dengan demikian belum memberikan gambaran yang jelas tentang bagaimana hal tersebut mempengaruhi variabel turnover intention dari karyawan secara keseluruhan. Selanjutnya mayoritas studi telah ditetapkan di negara-negara Barat. 
Investigasi dari anteseden dan hasil dari turnover intention lintas budaya di negara yang berbeda diperlukan untuk dinilai generalisasi temuan penelitian.

Mengingat Indonesia sebagai negara berkembang dan masih terus melakukan perbaikan di berbagai sector ekonomi, maka mengelola sumber daya manusia sebagai predictor sekaligus katalisator kinerja ekonomi menjadi sanagt penting dan juga genting (Asbari, 2011, 2020; Asbari et al., 2021a, 2021b; Asbari, Novitasari, Pebrina, et al., 2020; Asbari \& Novitasari, 2020b, 2021b; Jumiran et al., 2020; Lestari et al., 2020; Novitasari, Hutagalung, et al., 2020; Novitasari \& Asbari, 2020a; Sudiyono, Goestjahjanti, et al., 2020; Suprapti et al., 2020). Oleh karena itu itu, studi ini mencoba untuk mengisi kesenjangan penelitian dengan mengusulkan model integratif untuk mempelajari turnover intention karyawan di salah satu industri garmen di Indonesia. Model ini mengkaji bagaimana gaya kepemimpinan etis dan stres kerja dapat mempengaruhi turnover intention. Jadi, studi ini mengusulkan model perspektif karyawan tentang kepemimpinan etis, stres kerja yang mempengaruhi turnover intention. Peneliti menjelaskan metodologi secara rinci, diikuti dengan analisis dan hasil empiris. Akhirnya, penelitian ini menyimpulkan makalah dan membahas implikasi teoritis dan praktis dihasilkan oleh studi ini.

Turnover intention adalah sejauh mana karyawan berniat untuk keluar dari pekerjaan atau yang mempekerjakan mereka (Elçi et al., 2012). Menurut Harris \& Cameron (2005), turnover intention merupakan sebuah keinginan sadar dan sengaja untuk meninggalkan organisasi. Hal ini diukur dengan merujuk pada range waktu tertentu, dan dinilai sebagai pilihan paling akhir dalam urutan penarikan kognisi, termasuk untuk memutuskan berhenti dari aktivitas saat ini dan berniat untuk mencari pekerjaan lainnya. Turnover intention secara luas digunakan sebagai prediktor kognitif dan sebagai salah satu prediktor omset terkuat (Elçi et al., 2012; Harris \& Cameron, 2005; Shareef \& Atan, 2019). Penelitian sebelumnya telah menunjukkan bahwa turnover intention secara signifikan, negatif dan konsisten berhubungan dengan kepemimpinan etis (Elçi et al., 2012; Shareef \& Atan, 2019) dan stress kerja (Yang et al., 2016).

Turnover intention sebagaimana yang didefinisikan saat ini adalah preferensi karyawan untuk berhenti dari pekerjaannya. Niat untuk meninggalkan pekerjaan adalah "tekad yang disengaja dan sadar untuk keluar dari organisasi". Turnover intention yang saat ini dapat dipahami sebagai preferensi karyawan untuk keluar dari organisasinya merujuk bahwa karyawan tidak dapat tetap menjadi bagian organisasi (Iqbal et al., 2014). Perputaran karyawan akan menimbulkan biaya atau risiko kehilangan aset sosial yang signifikan. Sementara para peneliti yang melakukan penelitian ingin mengetahui perilaku turnover secara sempurna, sedangkan dalam realitas, seringkali rumit untuk mengamati perilaku secara empiris. Padahal pada kenyataannya, peneliti umumnya melakukan survei pada pekerja baru dan menanyakan alasan keinginan keluar masuk perusahaan. Niat untuk meninggalkan pekerjaan adalah prediktor konsisten dari perilaku turnover. Variabel-variabel penentu turnover karyawan memiliki aplikasi dan implikasi penting bagi karyawan yang sedang berpikir untuk berhenti, juga penting untuk manajemen yang dihadapkan pada kurangnya stabilitas karyawan, dalam orientasi dan bimbingan karyawan baru dan masalah keluaran organisasi yang melibatkan biaya tinggi.

Menurut Yang et al. (2016), stres kerja adalah reaksi merugikan yang dirasakan pegawai terhadap tekanan berlebih atau jenis perintah lain yang diberikan kepada mereka di tempat kerja. Efek mendasar stres kerja terhadap kinerja telah banyak dibahas baik teoritis maupun praktis (Sutardi et al., 2020), lebih khusus pengaruhnya terhadap turnover intention (Elçi et al., 2012). Kesimpulan penelitian membuktikan bahwa stres kerja adalah penyebab sejumlah besar sikap dan perilaku 
dan hasil seperti komitmen terhadap organisasi, ketidakpuasan kerja, dan niat keluar pekerjaan (Iqbal et al., 2014; Yang et al., 2016). Apalagi, ketika karyawan merasa stres dengan pekerjaannya, hal itu meningkatkan ketidakpuasan kerja mereka (Cahyono et al., 2020; Goestjahjanti et al., 2020; Novitasari, Asbari, et al., 2020; Singgih et al., 2020; Sudiyono, Fikri, et al., 2020).

Dekade terakhir ini menunjukkan pertumbuhan minat yang positif dalam pengembangan dan promosi teori dan konsep kepemimpinan etis dalam organisasi. "Kepemimpinan etis dianggap penting secara unik karena dampak pemimpin mungkin terhadap perilaku organisasi dan akhirnya pada kinerja organisasi." (Elçi et al., 2012) . Selain itu, "Kepemimpinan etis dipercaya untuk mengarahkan dan membimbing anggota organisasi menuju tujuan dan sasaran, yang bermanfaat bagi organisasi, anggotanya, pemangku kepentingan lainnya, dan masyarakat." (Babalola et al., 2016). Berdasarkan definisi para ahli tentang kepemimpinan etis dan sejalan dengan penelitian sebelumnya, Brown et al. (2005) menggambarkan, "Pemimpin etis sebagai jujur, dapat dipercaya, adil dan peduli. Pemimpin seperti itu membuat pilihan yang berprinsip dan adil serta menyusun lingkungan kerja dengan adil." Sejalan dengan Brown et al. (2005), Jong \& Hartog (2008) menilai, "Perilaku adil dan moral para pemimpin sebagai komponen inti dari kepemimpinan etis dan kami memberi label pada komponen kepemimpinan etis ini sebagai perhatian terhadap moralitas dan keadilan. Singkatnya, dibedakan moralitas dan keadilan, klarifikasi peran etis dan pembagian kekuasaan sebagai komponen kepemimpinan etis di tempat kerja." Brown et al. (2005:121) berpendapat bahwa, "Pemimpin etis dipandang sebagai sosok pemimpin yang transparan, dan menunjukkan komunikasi terbuka, mempromosikan dan menghargai perilaku etis di antara pengikut". Mengikuti perspektif Brown et al. (2005) namun dengan mengambil pendekatan yang sedikit lebih luas, peneliti fokus pada transparansi pemimpin, keterlibatan dalam komunikasi terbuka dengan pengikut dan klarifikasi harapan dan tanggung jawab sehingga karyawan jelas tentang apa yang diharapkan dari mereka. Hal ini merupakan bagian dari klarifikasi peran kepemimpinan etis. "Ikatan yang terjadi antara pemimpin etis dan karyawan lebih kuat yang menjadikan lingkungan yang menyenangkan di lokasi kerja; Oleh karena itu, hal ini yang menyebabkan komitmen karyawan yang lebih tinggi dan menurunkan niat untuk berpindah" (Shafique et al., 2018:75).

Sekaran \& Bougie (2003), menjelaskan, "Kerangka teoritis adalah fondasi di mana sebuah proyek penelitian. Dari kerangka teori ini, disusun rumusan hipotesis yang bisa diuji untuk memastikan apakah teori yang telah dirumuskan valid atau tidak. Selanjutnya akan dapat diuji dengan analisis statistik yang tepat." Untuk itu, penulis mendesain model penelitian sebagai mana disebut pada Gambar 1 sebagaimana berikut ini:

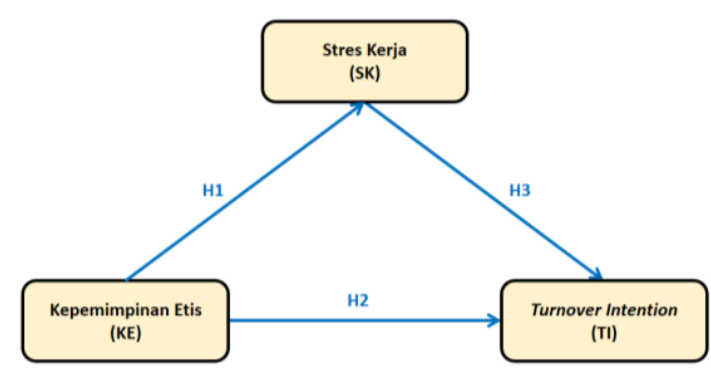

Gambar 1. Model Penelitian

Maka berdasarkan kajian pustaka di atas, maka disusun dipotesis sebagai berikut:

$\mathrm{H}_{1}$ : Kepemimpinan etis berpengaruh negatif dan signifikan terhadap stres kerja.

$\mathrm{H}_{2}$ : Kepemimpinan etis berpengaruh negatif dan signifikan terhadap turnover intention.

$\mathrm{H}_{3}$ : Stres kerja berpengaruh positif dan signifikan terhadap turnover intention. 
$\mathrm{H}_{4}$ : Kepemimpinan etis berpengaruh negatif dan signifikan terhadap turnover intention melalui stres kerja.

\section{METODE}

Menurut Creswell \& Creswell (2017), jika tujuan utama penelitian ini adalah guna mengetahui hubungan pengaruh antar variabel yang diteliti, maka pendekatan kuantitatif adalah yang terbaik. Metode penelitian kuantitatif adalah cocok dalam menguji teori dan hipotesis melalui penggunaan seperangkat alat statistik (Creswell \& Creswell, 2017). Oleh karena itu, penelitian ini memakai metode survei untuk menguji hipotesis yang dirumuskan dengan menggunakan kuesioner sebagai instrumen untuk memperoleh data yang diperlukan. Populasi penelitian terdiri dari 200 karyawan sebuah industri manufaktur di Kota Seribu Industri Tangerang. Seperti yang disarankan dan diadopsi dari penelitian sebelumnya, responden yang sesuai dari penelitian ini adalah para pengatur di perusahaan, mulai kepala regu, hingga manajer puncak, karena mereka memegang posisi kritis dalam organisasi yang memungkinkan mereka mampu memberikan informasi yang dapat dipercaya mengenai lingkungan dasar dan karakteristik organisasi mereka (Hung et al., 2010). Dengan menggunakan simple random sampling, 200 kuesioner dikirim secara online kepada populasi. 184 kuesioner dikembalikan dan valid, yang membentuk tingkat tanggapan 92\%.

Sifat penelitian ini melibatkan efek dependen antara konstruk laten dan variabel manifest. Oleh karena itu, model pengukuran reflektif cocok untuk penelitian ini (Hair Jr et al., 2017). Semua item yang diadopsi dinilai pada Skala Likert lima poin dari 1 (sangat tidak setuju) sampai 5 (sangat setuju). Turnover intention diukur dengan menggunakan tiga item (TI1-TI3) dari Cammann et al. (1979). Stres kerja diukur dengan menggunakan enam item (SK1-SK6) dari Keller (1984). Sedangkan untuk mengukur kepemimpinan etis, sepuluh item diadaptasi dari Brown et al (2005). Penelitian pendahuluan terhadap 30 responden dilakukan untuk memastikan keandalan dan validitas pengukuran di atas dalam konteks karyawan manufaktur di Indonesia. Hasil studi percontohan menunjukkan bahwa konsistensi internal konstruk utama berkisar antara 0,79 hingga 0,87, yang melebihi ambang batas 0,70 seperti yang disarankan oleh (J. F. Hair et al., 2014).

Teknik statistik paling populer di bawah Structural Equation Model (SEM) adalah berbasis kovarian pendekatan (CBSEM) dan teknik kuadrat terkecil parsial berbasis varian (PLS-SEM) (Sarstedt et al., 2014). Namun, PLS-SEM di decade terakhir ini memperoleh perhatian yang sangat luas di banyak orang disiplin ilmu seperti pemasaran, manajemen strategis, sistem informasi manajemen, dan cabang keilmuan lainnya (Hair et al., 2012). Kemampuan PLS-SEM untuk menangani permasalahan problematic modelling yang biasa terjadi di lingkungan social ilmu pengetahuan seperti karakteristik data yang tidak biasa (misalnya data non-normal) dan model yang sangat kompleks adalah alasan penting di balik peningkatan penggunaan pendekatan ini. Mengingat keuntungan dari pendekatan ini, penelitian ini menggunakan PLS-SEM untuk menguji secara keseluruhan dari hipotesis yang diajukan. Perangkat lunak SmartPLS dilakukan untuk mengevaluasi masing-masing outer model dan inner model. Pengujian pada outer model diperlukan untuk memastikan keandalan dan validitas pengukuran, sedangkan hipotesis yang diperkenalkan diperiksa melalui inner model. Sebelum menguji responden seluruhnya, peneliti melakukan uji pendahuluan terhadap kuesioner yang disusun. Dengan menggunakan sampel uji pendahuluan sebanya 30 responden, hasilnya menunjukkan bahwa item-item pada variabel kepemimpinan etis harus dibuang sebagian karena tidak valid dan tidak reliable. Selanjutnya, hasil akhir kuesioner yang kemudian digunakan pada penelitian ini sebagaimana disebutkan pada Tabel 1 . 
Tabel 1. Daftar Item Penelitian

\begin{tabular}{|c|c|}
\hline Notasi & Item \\
\hline \multicolumn{2}{|c|}{ Kepemimpinan Etis (KE) } \\
\hline KE1 & $\begin{array}{l}\text { Memberikan contoh bagaimana } \\
\text { melakukan sesuatu dengan cara yang } \\
\text { benar dalam kaitannya dengan etika }\end{array}$ \\
\hline KE2 & $\begin{array}{l}\text { Melakukan kehidupan pribadinya } \\
\text { dengan cara yang etis }\end{array}$ \\
\hline KE3 & $\begin{array}{l}\text { Mendisiplinkan karyawan yang } \\
\text { melanggar standar etika }\end{array}$ \\
\hline KE4 & $\begin{array}{l}\text { Mendefinisikan kesuksesan tidak hanya } \\
\text { dengan hasil tetapi juga dari cara } \\
\text { memperolehnya }\end{array}$ \\
\hline KE5 & $\begin{array}{l}\text { Membuat keputusan yang adil dan } \\
\text { seimbang }\end{array}$ \\
\hline \multicolumn{2}{|c|}{ Stres Kerja (SK) } \\
\hline SK1 & Saya merasa lelah setelah bekerja \\
\hline SK2 & $\begin{array}{l}\text { Saya khawatir tentang masalah setelah } \\
\text { bekerja. }\end{array}$ \\
\hline SK3 & $\begin{array}{l}\text { Saya merasa sulit untuk melepas lelah } \\
\text { setelah bekerja }\end{array}$ \\
\hline SK4 & $\begin{array}{l}\text { Saya sering mengalami stres dan } \\
\text { ketegangan terkait pekerjaan. }\end{array}$ \\
\hline SK5 & $\begin{array}{l}\text { Saya menganggap pekerjaan saya } \\
\text { sangat berat dan terlalu menuntut }\end{array}$ \\
\hline SK6 & Saya merasa lelah setelah bekerja. \\
\hline \multicolumn{2}{|c|}{ Turnover Intention (TI) } \\
\hline TI1 & $\begin{array}{l}\text { Saya kemungkinan akan secara aktif } \\
\text { mencari pekerjaan baru di tahun depan. }\end{array}$ \\
\hline TI2 & Saya sering berpikir untuk berhenti. \\
\hline TI3 & $\begin{array}{l}\text { Saya mungkin mencari pekerjaan baru di } \\
\text { tahun depan. }\end{array}$ \\
\hline
\end{tabular}

\section{HASIL DAN PEMBAHASAN}

Total terdapat 184 karyawan yang berpartisipasi. Sebagaimana disebutkan pada Tabel 2, responden memiliki kelompok usia yang beragam, berkisar antara di bawah usia 29 tahun 246\%), 30-49 tahun (48\%), dan lebih dari usia 50 tahun (28\%). Status kepegawaian mereka beragam, dimana $38 \%$ di antaranya adalah pegawai tetap, 62\% di antaranya pegawai kontrak. Lama kerja mereka juga beragam, 34\% di antaranya di bawah 5 tahun, $50 \%$ sudah bekerja antara 510 tahun, dan $16 \%$ sisanya telah bekerja lebih dari 10 tahun. Pendidikan tertinggi responden adalah mayoritas setingkat SLTA (SMA/SMK) yakni $75 \%$, dan sisanya $23 \%$ lulusan SMP serta lulusan sarjana sebanyak $2 \%$.
Tabel 2. Deskripsi Sampel

\begin{tabular}{llll}
\hline Kriteria & & Jml. & $\%$ \\
\hline Usia & $<29$ thn. & 44 & $24 \%$ \\
& $30-49$ thn. & 88 & $48 \%$ \\
& $>50$ thn. & 52 & $28 \%$ \\
Masa kerja sebagai & $<5$ thn. & 63 & $34 \%$ \\
karyawan & $5-10$ thn. & 92 & $50 \%$ \\
& $>10$ thn. & 29 & $16 \%$ \\
Ijazah tertinggi & SMP & 42 & $23 \%$ \\
& SMA & 138 & $75 \%$ \\
& $\geq$ S1 & 4 & $2 \%$ \\
\hline
\end{tabular}

Sumber: Data Diolah (2021)

Tahap pengujian model pengukuran meliputi pengujian validitas konvergen, validitas diskriminan. Sementara untuk menguji reliabilitas konstruk digunakan nilai cronbach's alpha dan composite reliability. "Hasil analisis PLS dapat digunakan untuk menguji hipotesis penelitian jika seluruh indikator dalam model PLS telah memenuhi syarat validitas konvergen, validitas deskriminan dan uji reliabilitas. Uji validitas konvergen dilakukan dengan melihat nilai loading factor masing-masing indikator terhadap konstruknya. Pada sebagian besar referensi, bobot faktor sebesar 0,7 atau lebih dianggap memiliki validasi yang cukup kuat untuk menjelaskan konstruk laten." Ghozali (2014) mengatakan batas minimal besarnya loading factor pada penelitian ini yang diterima adalah 0,7 dan "Dengan syarat nilai AVE setiap konstruk > 0,5" (Ghozali, 2014:123). Setelah melalui pengolahan SmartPLS 3,0 seluruh indikator telah memiliki nilai loading factor di atas 0,7 dan nilai AVE di atas 0,5. Model fit atau valid dari penelitian ini dapat dilihat pada Gambar 2. Jadi dengan demikian, validitas konvergen dari model penelitian ini sudah memenuhi syarat. Nilai loadings, cronbach's alpha, composite reliability dan AVE setiap konstruk selengkapnya dapat dilihat Tabel 3.

Ghozali (2014) menyebutkan, "Discriminant validity dilakukan untuk memastikan bahwa setiap konsep dari masing-masing variabel laten berbeda dengan variabel laten lainnya. Model mempunyai discriminant validity yang baik jika nilai kuadrat AVE masing-masing 
konstruk eksogen (nilai pada diagonal) melebihi korelasi antara konstruk tersebut dengan konstruk lainnya (nilai di bawah diagonal)." Sedangkan Fornell \& Larcker (1981:39) menjelaskan, "Hasil pengujian discriminant validity adalah dengan menggunakan nilai kuadrat AVE, yakni dengan melihat Fornell-Larcker Criterion Value diperoleh." Sebagaimana ditunjukkan pada Tabel 3. Hasil uji validitas deskriminan pada Tabel 4 menunjukkan bahwa seluruh konstruk telah memiliki nilai akar kuadrat AVE di atas nilai korelasi dengan konstruk laten lainnya (melalui kriteria FornellLarcker), sehingga dapat disimpulkan bahwa model penelitian ini telah memenuhi syarat validitas deskriminan (Fornell \& Larcker, 1981).

Selanjutnya dilakukan evaluasi collinearity guna memeriksa ada tidaknya masalah collinearity pada model. "Untuk menemukan collinearity tersebut, diperlukan statistik collinearity VIF dari setiap konstruk. Jika VIF lebih dari 5, maka model memiliki collinearity." Demikian penjelasan Hair et al., (2014:107). Seperti yang ditampilkan pada Tabel 5, nampak bahwa semua skor VIF kurang dari 5, yakni hasil dari model struktural colinearity mengungkapkan nilai VIF di bawah 2. Hal ini menunjukkan bahwa model penelitian ini tidak ada masalah multikolinearitas.

Ghozali (2014) menjelaskan,

"Reliabilitas konstruk dapat dinilai dari nilai cronbach's alpha dan composite reliability dari masing-masing konstruk. Nilai composite reliability dan cronbach's alpha yang disarankan adalah lebih dari 0,7." Hasil uji reliabilitas pada Tabel 3 menunjukkan bahwa seluruh konstruk telah memiliki nilai composite reliability dan cronbach's alpha lebih besar dari 0,7 (>0,7). Kesimpulannya, seluruh konstruks telah memenuhi reliabilitas yang dipersyaratkan.

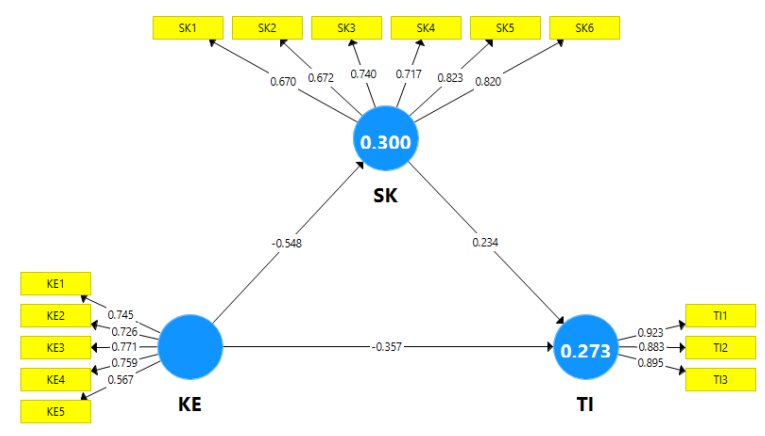

Gambar 2. Model Penelitian Valid Sumber: Hasil Pengolahan SmartPLS 3.0 (2021)

Tabel 3. Data Items Loadings, Cronbach's Alpha, Composite Reliability, dan Average Variance Extracted (AVE)

\begin{tabular}{|c|c|c|c|c|c|}
\hline Variabel & Items & Loadings & $\begin{array}{l}\text { Cronbach } \\
\text { 's Alpha }\end{array}$ & $\begin{array}{l}\text { Composite } \\
\text { Reliability }\end{array}$ & AVE \\
\hline \multirow{5}{*}{$\begin{array}{l}\text { Kepemi } \\
\text { mpinan } \\
\text { Etis } \\
\text { (KE) }\end{array}$} & KE1 & 0,745 & \multirow[t]{5}{*}{0,762} & \multirow[t]{5}{*}{0,840} & \multirow[t]{5}{*}{0,515} \\
\hline & KE2 & 0,726 & & & \\
\hline & KE3 & 0,771 & & & \\
\hline & KE4 & 0,759 & & & \\
\hline & KE5 & 0,567 & & & \\
\hline Stres & SK1 & 0,670 & \multirow[t]{6}{*}{0,839} & \multirow[t]{6}{*}{0,880} & \multirow[t]{6}{*}{0,552} \\
\hline Kerja & SK2 & 0,672 & & & \\
\hline \multirow{4}{*}{ (SK) } & SK3 & 0,740 & & & \\
\hline & SK4 & 0,717 & & & \\
\hline & SK5 & 0,823 & & & \\
\hline & SK6 & 0,820 & & & \\
\hline Turnover & TI1 & 0,923 & \multirow{3}{*}{0,883} & \multirow{3}{*}{0,928} & \multirow{3}{*}{0,810} \\
\hline Intention & TI2 & 0,883 & & & \\
\hline (TI) & TI3 & 0,895 & & & \\
\hline
\end{tabular}

Sumber: Hasil Pengolahan SmartPLS 3.0 (2021)

Tabel 4. Discriminant Validity

\begin{tabular}{llll}
\hline Variabel & KE & SK & TI \\
\hline Kepemimpinan Etis (KE) & 0,717 & & \\
Stres Kerja (SK) & $-0,548$ & 0,743 & \\
Turnover Intention (TI) & $-0,485$ & 0,429 & 0,900 \\
\hline Sumber: Hasil Pengolahan SmartPLS $3.0(2021)$
\end{tabular}

Tabel 5. Collinearity (VIF)

\begin{tabular}{lrrc}
\hline Variabel & KE & SK & TI \\
\hline Kepemimpinan Etis (KE) & & 1,000 & 1,429 \\
Stres Kerja (SK) & & & 1,429 \\
Turnover Intention (TI) & & & \\
\hline Surn
\end{tabular}

Sumber: Hasil Pengolahan SmartPLS 3.0 (2021)

Tabel 6. Nilai $R$ Square

\begin{tabular}{lcc}
\hline Variabel & $R$ Square & $\begin{array}{l}R \\
\text { Adjusted }\end{array}$ \\
\hline Stres Kerja (SK) & 0,300 & 0,295 \\
Turnover Intention (TI) & 0,273 & 0,263 \\
\hline
\end{tabular}

Sumber: Hasil Pengolahan SmartPLS 3.0 (2021) 
Tabel 7. Hypotheses Testing

\begin{tabular}{|c|c|c|c|c|c|c|}
\hline Hypotheses & Relationship & Beta & $\mathrm{SE}$ & $\begin{array}{c}T \\
\text { Statistics }\end{array}$ & $\begin{array}{c}P- \\
\text { Values }\end{array}$ & Decision \\
\hline H1 & $\mathrm{KE}$-> SK & $-0,548$ & 0,061 & 8,944 & 0,000 & Didukung \\
\hline $\mathrm{H} 2$ & $\mathrm{KE}$-> TI & $-0,357$ & 0,111 & 3,210 & 0,001 & Didukung \\
\hline $\mathrm{H} 3$ & SK -> TI & 0,234 & 0,100 & 2,338 & 0,020 & Didukung \\
\hline $\mathrm{H} 4$ & $\begin{array}{l}\mathrm{KE}->\mathrm{SK} \\
\Rightarrow \mathrm{TI}\end{array}$ & $-0,128$ & 0,057 & 2,231 & 0,026 & Didukung \\
\hline
\end{tabular}

Pengujian hipotesis dalam metode PLS disebut juga sebagai Uji Inner Model. Uji ini meliputi uji signifikansi pengaruh langsung dan tidak langsung serta pengukuran besarnya pengaruh variabel eksogen terhadap variabel endogen. Untuk mengetahui pengaruh kepemimpinan etis terhadap turnover intention melalui stress kerja sebagai variable mediasi dibutuhkan uji pengaruh langsung dan tidak langsung. Uji pengaruh dilakukan dengan menggunakan uji t-statistiks dalam model analisa partial least squared (PLS) dengan menggunakan bantuan software SmartPLS 3,0. Melalui teknik boothstrapping, diperoleh nilai $R$ Square dan nilai uji signifikansi sebagaimana Tabel 6 dan Tabel 7. Hasilnya adalah semua hipotesis di dukung, yakni: Kepemimpinan etis berpengaruh negatif dan signifikan terhadap stres kerja (H1 didukung). Kepemimpinan etis berpengaruh negatif dan signifikan terhadap turnover intention ( $\mathrm{H} 2$ didukung). Stres kerja berpengaruh positif dan signifikan terhadap turnover intention (H3 didukung). Kepemimpinan etis berpengaruh negatif dan signifikan terhadap turnover intention melalui stres kerja ( $\mathrm{H} 4$ didukung).

\section{Pembahasan}

Berdasarkan Tabel 6, nilai $R$ Square stress kerja (SK) sebesar 0,30 yang berarti bahwa variabel stres kerja (SK) mampu dijelaskan oleh variabel kepemimpinan etis (KE) sebesar $30 \%$, sedangkan $70 \%$ sisanya dijelaskan oleh variabel lain yang tidak dibahas dalam studi ini. Sementara itu, nilai $R$ Square turnover intention (TI) sebesar 0,273 yang berarti bahwa variabel turnover intention (TI) mampu dijelaskan oleh variabel kepemimpinan etis (KE) dan stres kerja (SK) sebesar 27,3\%, sedangkan 72,7\% sisanya dijelaskan oleh variabel lain yang tidak dibahas dalam studi ini. Sedangkan Tabel 6 menampilkan nilai-nilai $t$-statistics dan p-values yang menunjukkan pengaruh antar variabel penelitian yang telah disebutkan.

Sasaran utama dari penelitian ini adalah guna mengetahui pengaruh dari beberapa persepsi, dan sikap terkait pekerjaan karyawan terhadap intensi turnover mereka, yang sebagian besar memiliki konsekuensi yang berbahaya bagi organisasi. Kepemimpinan merupakan faktor sangat penting untuk menurunkan tingkat turnover, tetapi stres merupakan faktor lain yang justru meningkatkannya. Secara khusus dalam studi ini berkonsentrasi pada pengaruh kepemimpinan etis dan persepsi efektivitas pemimpin dari karyawan pada tingkat stres dan niat keluar. Ada sejumlah penyebab stres di tempat kerja yang pada akhirnya menghasilkan stres bagi karyawan; karena tempat kerja akan terus memproduksi stres, organisasi dan manajernya perlu menemukan cara untuk mengurangi konsekuensi negatif dari stres yang dirasakan ini (Zhang dan Lee, 2010). Pemimpin memiliki peran penting untuk mengurangi stres terkait pekerjaan. Perilaku pemimpin memiliki pengaruh penting terhadap perilaku karyawan, seperti kepuasan kerja dan komitmen organisasi (Van Knippenberg et al, 2007). Penting bagi para pemimpin untuk mendapatkan kepercayaan dan kesetiaan pengikut mereka (Aronson, 2001). Ini dapat diwujudkan kepemimpinan etis yang menyeluruh dan efektivitas pemimpin. Kepemimpinan etis memberikan komitmen dan loyalitas karyawan (Trevino et al, 2000). Ketika karyawan percaya diri dan loyal kepada pimpinannya, maka stres yang terkait dengan pekerjaannya akan berkurang dan mereka tidak memiliki niat yang kuat untuk keluar dari organisasi.

Menurut hasil studi ini, kepemimpinan etis mempengaruhi stres terkait pekerjaan dan niat berpindah 
secara negatif. Stres terkait pekerjaan berpengaruh positif dan signifikan terhadap turnover intention. Pengaruh stres kerja terkait pekerjaan terhadap turnover intentions lebih rendah jika dibandingkan dengan variabel kepemimpinan etis. Selain itu, temuan menunjukkan bahwa stres kerja secara parsial memediasi baik hubungan antara kepemimpinan etis dan turnover intention. Selanjutnya, pengaruh kepemimpinan etis terhadap turnover intention menurun ketika stres kerja dimasukkan dalam model, yang secara parsial mengimplikasikan bahwa kepemimpinan etis mengurangi stres kerja, yang pada gilirannya mengurangi turnover intention.

\section{Kesimpulan}

Temuan studi ini mengkonfirmasi bahwa kepemimpinan etis dan efektivitas pemimpin secara negatif mempengaruhi stres kerja dan turnover intention. Sedangkan stres kerja berpengaruh positif dan signifikan terhadap turnover intention. Hal ini menyiratkan bahwa jenis kepemimpinan yang etis dan efektif pada saat yang sama membantu mengurangi stres dan pergantian. Temuan studi ini dan implikasinya dapat mengisi kekosongan literature tentang praktik kepemimpinan etis di industri garmen di Indonesia.

Namun demikian, penelitian ini juga bukannya tanpa batasan. Tergantung pada analisis cross sectional adalah batasan utama dari penelitian ini. Tanpa menggunakan studi longitudinal, hubungan antara stres dan intensi turnover tidak dapat dipahami dengan baik. Penelitian selanjutnya tentang topik ini harus dikembangkan menjadi longitudinal. Dimungkinkan juga untuk memperluas model teoritis dengan memasukkan variabel dependen tambahan seperti komitmen organisasi, kinerja pekerjaan, kelelahan, dan ketidakhadiran.

\section{DAFTAR PUSTAKA}

Asbari, M. (2011). Kepemimpinan Transformasional: Landasan Menuјu World Class Company. https://kangmasduki.com/2011/05/31/ke pemimpinan-transformasionallandasan-menuju-world-class-company/

Asbari, M. (2020). Is transformational leadership suitable for future organizational needs?. International Journal of Sociology, Policy and Law (Ijospl), 1(01), 51-55.

Asbari, M., \& Novitasari, D. (2020a). Pengaruh Kesiapan untuk Berubah di Masa Pandemi Covid-19: Apa yang Dibutuhkan Pemimpin untuk Menjaga Kinerja. Jurnal Ekonomika: Manajemen, Akuntansi, Dan Perbankan Syari'ah, 9(2), 1-17. https://doi.org/https://doi.org/10.24903/j e.v9i2.932

Asbari, M., \& Novitasari, D. (2020b). The role of readiness for change on parttimer employee performance: Analysis of transformational leadership practice in convection industry. Journal of Communication Education (JOCE), 14(02).

Asbari, M., \& Novitasari, D. (2021a). Pengaruh Aktivitas Berbagi Pengetahuan dan Mediasi Budaya terhadap Kemampuan Inovasi Guru. JMSP (Jurnal Manajemen Dan Supervisi Pendidikan), 5(1), 324-334.

Asbari, M., \& Novitasari, D. (2021b). Pengaruh Authentic Leadership terhadap Mentalitas Siap Berubah dan Kinerja Pegawai Paruh Waktu. Business Management Journal, 17(1), 73-88. https://doi.org/http://dx.doi.org/10.3081 3/bmj

Asbari, M., Novitasari, D., Gazali, G., Silitonga, N., \& Pebrina, E. T. (2020). Analisis Kesiapan untuk Berubah di Masa Pandemi Covid-19: Studi Pengaruh Kepemimpinan Transformasional terhadap Kinerja Karyawan. Jurnal Perspektif, 18(2), 147-159.

https://ejournal.bsi.ac.id/ejurnal/index.p 
hp/perspektif/article/view/8576

Asbari, M., Novitasari, D., \& Goestjahjanti, F. S. (2020). Mempertahankan Kinerja Karyawan di Masa Pandemi Covid-19: Studi Kasus pada Industri Ritel. JMK (Jurnal Manajemen \& Kewirausahaan), 5(3), 183-203.

Asbari, M., Novitasari, D., Pebrina, E. T., \& Santoso, J. (2020). Work-family conflict and employee performance during covid-19 pandemic: what is the role of mental readiness to change? JPBM (Jurnal Pendidikan Bisnis Dan Manajemen), 6(2).

Asbari, M., \& Prasetya, A. B. (2021). Managerial Coaching: Rahasia Membangun Kinerja, Komitmen Tim dan Modal Psikologis Guru. Edumaspul - Jurnal Pendidikan, 5(1), 490-506. https://ummaspul.ejournal.id/maspuljr/article/view/1248

Asbari, M., Purba, J. T., Hariandja, E. S., \& Sudibjo, N. (2021a). From leadership to innovation: managing employee creativity. Jurnal Manajemen Strategi Dan Aplikasi Bisnis, 4(1), 143-154.

Asbari, M., Purba, J. T., Hariandja, E. S., \& Sudibjo, N. (2021b). Membangun Kesiapan Berubah dan Kinerja Karyawan: Kepemimpinan Transformasional versus Transaksional. Jurnal Ilmiah Manajemen Dan Bisnis, 22(1), 54-71.

Babalola, M. T., Stouten, J., \& Euwema, M. (2016). Frequent change and turnover intention: The moderating role of ethical leadership. Journal of Business Ethics, 134(2), 311-322.

Brown, M. E., Treviño, L. K., \& Harrison, D. A. (2005). Ethical leadership: A social learning perspective for construct development and testing. Organizational Behavior and Human Decision Processes, 97(2), 117-134.

Cahyono, Y., Novitasari, D., Sihotang, M., Aman, M., Fahlevi, M., Nadeak, M., Siahaan, M., Asbari, M., \& Purwanto, A. (2020). The effect of transformational leadership dimensions on job satisfaction and organizational commitment: case studies in private university Lecturers. Solid State Technology, 63(1s), 158-184. http://www.solidstatetechnology.us/inde x.php/JSST/article/view/707

Cammann, C., Fichman, M., Jenkins, D., \& Klesh, J. (1979). The Michigan organizational assessment questionnaire. Unpublished Manuscript, University of Michigan, Ann Arbor, 71138.

Chin, W. (1998). The Partial Least Squares Approach to Structural Equation Modeling (E. Modern Methods for Business Research, In: G. A. Marcoulides (ed.)). Lawrence Erlbaum Associates Publisher.

Creswell, J. W., \& Creswell, J. D. (2017). Research design: Qualitative, quantitative, and mixed methods approaches. Sage publications.

Elçi, M., Şener, İ., Aksoy, S., \& Alpkan, L. (2012). The impact of ethical leadership and leadership effectiveness on employees' turnover intention: the mediating role of work related stress. Procedia - Social and Behavioral Sciences, 58, 289-297. https://doi.org/10.1016/j.sbspro.2012.09 .1003

Fornell, C., \& Larcker, D. F. (1981). Evaluating structural equation models with unobservable variables and measurement error. Journal of Marketing Research, 18(1), 39. https://doi.org/10.2307/3151312

Ghozali, I. (2014). Structural Equation Modeling, Metode Alternatif dengan Partial Least Square (PLS) (4th ed.). Badan Penerbit Universitas Diponegoro.

Goestjahjanti, S. F., Novitasari, D., Hutagalung, D., Asbari, M., \& Supono, J. (2020). Impact of talent management, authentic leadership and employee engagement on job satisfaction: Evidence from south east asian industries. Journal of Critical Reviews, 7(19), $\quad$ 67-88. http://www.jcreview.com/?mno=10198 
3

Hair, J. F., Black, W. C., Babin, B. J., \& Anderson, R. E. (2010). Multivariate Data Analysis (7th ed.). Pearson Prentice Hall.

Hair, J. F., Hult, G. T., Ringle, C. M., \& Sarstedt, M. (2014). A primer partial least squaresstructural equation modeling (PLS-SEM). SAGE Publications.

Hair, Joe F, Sarstedt, M., Ringle, C. M., \& Mena, J. A. (2012). An assessment of the use of partial least squares structural equation modeling in marketing research. Journal of the Academy of Marketing Science, 40(3), 414-433.

Hair Jr, J. F., Sarstedt, M., Ringle, C. M., \& Gudergan, S. P. (2017). Advanced issues in partial least squares structural equation modeling. saGe publications.

Harris, G. E., \& Cameron, J. E. (2005). Multiple dimensions of organizational identification and commitment as predictors of turnover intentions and psychological well-being. Canadian Journal of Behavioural Science, 37(3), 159-169.

https://doi.org/https://doi.org/10.1037/h 0087253

Hung, R. Y.-Y., Lien, B. Y.-H., Fang, S.-C., \& McLean, G. N. (2010). Knowledge as a facilitator for enhancing innovation performance through total quality management. Total Quality Management, 21(4), 425-438.

Iqbal, S., Ehsan, S., Rizwan, M., \& Noreen, M. (2014). The impact of organizational commitment, job satisfaction, job stress and leadership support on turnover intention in educational institutes. International Journal of Human Resource Studies, 4(2), 181. https://doi.org/10.5296/ijhrs.v4i2.5906

Jong, J. P. J. D., \& Hartog, D. N. Den. (2008). Innovative Work Behavior: Measurement and Validation. Scientific Analysis of Entrepreneurship and SMEs, November, 1-27.

Jumiran, Novitasari, D., Nugroho, Y. A., Sutardi, D., Sasono, I., \& Asbari, M.
(2020). Pengaruh Dimensi Kepemimpinan Transformasional terhadap Kepuasan Kerja dan Komitmen Organisasional: Studi Kasus pada Dosen Perguruan Tinggi Swasta. EduPsyCouns: Journal of Education, Psychology and Counseling, 2(1), 600621.

Keller, D. (1984). Humor as Therapy. WI: Med-Psych Publications.

Lestari, B., Novitasari, D., Silitonga, N., \& Asbari, M. (2020). The effect of recruitment and career development on the spirit of teachers'work performance in Mts Nurul Huda. Journal of Industrial Engineering \& Management Research (JIEMAR), 1(2), 108-121.

Lin, C.-P., \& Liu, M.-L. (2017). Examining the effects of corporate social responsibility and ethical leadership on turnover intention. Personnel Review.

Mullen, P. R., Malone, A., Denney, A., \& Dietz, S. S. (2018). Job stress, burnout, job satisfaction, and turnover intention among student affairs professionals. College Student Affairs Journal, 36(1), 94-108.

https://doi.org/https://doi.org/10.1353/cs j.2018.0006

Nazelina, M., Novitasari, D., Fikri, M. A. A., \& Asbari, M. (2020). The effect of brand image, price and service quality on consumer decisions using delivery services. Journal of Industrial Engineering \& Management Research (JIEMAR), 1(3), 135-147.

Negiş Işik, A. (2020). Ethical leadership and school effectiveness: The mediating roles of affective commitment and job satisfaction. International Journal of Educational Leadership and Management, 8(1), 60-87. https://doi.org/10.17583/ijelm.2020.411 4

Novitasari, D., \& Asbari, M. (2020a). Pengaruh Kepemimpinan Transformasional terhadap Kinerja Karyawan: Peran Kesiapan untuk Berubah sebagai Mediator. Jurnal Manajemen, 10(2), 84-99. 
Novitasari, D., \& Asbari, M. (2020b). Urgensi Kepemimpinan dan Mentalitas Siap Berubah Terhadap Kinerja Pegawai di Musim Pandemi Covid-19. Jurnal REKOMEN (Riset Ekonomi Manajemen), 4(1), 66-80.

Novitasari, D., Asbari, M., \& Sasono, I. (2021). Analisis Pengaruh Religiusitas dan Kualitas Pelayanan terhadap Kepuasan Kerja: Studi Kasus pada Karyawan Industri Manufaktur. Jurnal Manajemen Strategi Dan Aplikasi Bisnis, 4(1), 117-130.

Novitasari, D., Asbari, M., Wijayanti, L. M., Hyun, C. C., \& Farhan, M. (2020). The role of religiosity, leadership style, job satisfaction and organizational citizenship behavior mediation on woman teachers' performance. Solid State Technology, 63(6), 2953-2967. http://solidstatetechnology.us/index.php /JSST/article/view/3380

Novitasari, D., Goestjahjanti, F. S., \& Asbari, M. (2020). The role of readiness to change between transformational leadership and performance: evidence from a hospital during Covid-19 Pandemic. APMBA (Asia Pacific Management and Business Application), 9(1), 37-56. https://doi.org/10.21776/ub.apmba.2020 .009.01.4

Novitasari, D., Hutagalung, D., Nugroho, Y. A., Pramono, T., Asbari, M., Nuryanti, Y., \& Yuwono, T. (2020). Does genetic personality and parenting style influence students' character building? Journal of Critical Reviews, 7(19), 119 129.

Sarstedt, M., Ringle, C. M., Smith, D., Reams, R., \& Hair Jr, J. F. (2014). Partial least squares structural equation modeling (PLS-SEM): A useful tool for family business researchers. Journal of Family Business Strategy, 5(1), 105115.

Sekaran, U., \& Bougie, R. (2003). Research Methods For Business: A Skill Building Approach (Sixth edit). John Wiley and Sons, Inc.
Shafique, I., N Kalyar, M., \& Ahmad, B. (2018). The nexus of ethical leadership, job performance, and turnover intention: The mediating role of job satisfaction. Interdisciplinary Description of Complex Systems: INDECS, 16(1), 71-87.

Shareef, R. A., \& Atan, T. (2019). The influence of ethical leadership on academic employees' organizational citizenship behavior and turnover intention: Mediating role of intrinsic motivation. Management Decision.

Singgih, E., Iskandar, J., Goestjahjanti, F. S., Fahlevi, M., Nadeak, M., Fahmi, K., Anwar, R., Asbari, M., \& Purwanto, A. (2020). The role of job satisfaction in the relationship between transformational leadership, knowledge management, work environment and performance. Solid State Technology, 63(2s), 293-314. http://www.solidstatetechnology.us/inde x.php/JSST/article/view/1556

Sudiyono, R. N., Fikri, M. A. A., Asbari, M., Suroso, Nugroho, Y. A., \& Singgih, E. (2020). The role of employee engagement in the relationship between authentic leadership, talent management and job satisfaction. International Journal of Advanced Science and Technology, 29(5), 11809-11836. http://sersc.org/journals/index.php/IJAS T/article/view/25377

Sudiyono, R. N., Goestjahjanti, F. S., Asbari, M., Agistiawati, E., Fayzhall, M., Yani, A., Winanti, W., Yuwono, T., Nurasiah, N., \& Yulia, Y. (2020). Meningkatkan Komitmen dan Kinerja Dosen: Apa Peran Manajemen Perguruan Tinggi? EduPsyCouns: Journal of Education, Psychology and Counseling, 2(1), 337352.

Suprapti, S., Asbari, M., Cahyono, Y., \& Mufid, A. (2020). Leadership style, organizational culture and innovative behavior on public health center performance during Pandemic Covid19. Journal of Industrial Engineering \& Management Research, 1(2), 76-88. 
Sutardi, D., Novitasari, D., Asbari, M., Silitonga, N., Nugroho, Y. A., Hutagalung, D., Mustofa, Chidir, G., Basuki, S., \& Yuwono, T. (2020). Pengaruh Work-Family Conflict, Stres Kerja dan Social Support terhadap Kepuasan Kerja: Studi Kasus pada Guru Wanita di Tangerang. EduPsyCouns: Journal of Education, Psychology and Counseling, 2(1), 482-498. https://ummaspul.ejournal.id/Edupsycouns/article/view/51 3

Yang, H.-C., Ju, Y.-H., \& Lee, Y.-C. (2016). Effects of job stress on self-esteem, job satisfaction, and turnover intention. Journal of Transnational Management, 21(1), 29-39. 